CENTRE POUR LA RECHERCHE ECONOMIQUE ET SES APPLICATIONS

Document de travail (Docweb) no 1507

\title{
Rising Aspirations Dampen Satisfaction
}

Andrew E. Clark

Akiko Kamesaka

Teruyuki Tamura 


\title{
Rising Aspirations Dampen Satisfaction ${ }^{1}$
}

\author{
Andrew E. Clark ${ }^{2}$, Akiko Kamesaka ${ }^{3}$ and Teruyuki Tamura ${ }^{4}$
}

\begin{abstract}
It is commonly-believed that education is a good thing for individuals. Yet its correlation with subjective well-being is most often only weakly positive, or even negative, despite the many associated better individual-level outcomes We here square the circle using novel Japanese data on happiness aspirations. If reported happiness comes from a comparison of outcomes to aspirations, then any phenomenon raising both at the same time will have only a muted effect on reported wellbeing. We find that around half of the happiness effect of education is cancelled out by higher aspirations, and suggest a similar dampening effect for income.
\end{abstract}

Keywords: Education, Satisfaction, Aspirations, Income.

JEL Classification: I26, I31.

1 We are very grateful to the Editor, Colin Green, and two anonymous referees for incisive and constructive comments. We thank Shiho Kawano, Yukinobu Kitamura, Fumio Ohtake, Tadashi Yagi, and session participants at the 2013 Autumn Meeting of the Japanese Economic Association, and the 7th Annual Meeting of the Association of Behavioral Economics and Finance for many helpful comments. We also thank Susumu Kuwahara for supporting this research project at the Economic and Social Research Institute (ESRI), Cabinet Office, Government of Japan. The second author"s research is partly supported by Grants-in-Aid for Scientific Research (C) 24530358 from the Japan Society for the Promotion of Science.

2 PSE, 48 Boulevard Jourdan, 75014 Paris, France. Tel.: +33-1-43-13-63-29. E-mail: Andrew.Clark@ens.fr.

3 Aoyama Gakuin University, 4-4-25 Shibuya, Shibuya-ku, Tokyo, Japan. Tel.: +81-3-3409-6269. E-mail: akiko@busi.aoyama.ac.jp. Economic and Social Research Institute (ESRI), Cabinet Office, Government of Japan.

4 Sophia University, 7-1 Kioi-Cho, Chiyoda-ku, Tokyo, Japan. E-mail:tetamura@gmail.com. 


\title{
Rising Aspirations Dampen Satisfaction
}

\author{
Andrew E. Clark, Akiko Kamesaka and Teruyuki Tamura
}

\section{Introduction}

There has been a great deal of empirical work on the correlates of self-reported happiness or subjective well-being over the past two decades across the social sciences. One potential mystery in this fast-growing literature is why the correlation between satisfaction and education is often found to be only weakly positive, or even negative.

A number of explanations have been proposed. One possibility is that of sorting, whereby 'naturally' unhappy people are more likely to choose to become educated. In principle, this hypothesis can be tested using panel data. ${ }^{1}$ In practice, however, many of the adults who appear in large-scale panel data sets do not change their levels of education. To evaluate the well-being effect of education using panel data, we would then require data that provides information on children's initial levels of subjective well-being, and then follow the same individuals up to the time at which their education is completed. The British Household Panel Survey (BHPS), ${ }^{2}$ for example, has from Wave 4 included information on children of household members aged 11 to 15 that would potentially allow such analysis. A more complete picture of childhood development can be obtained, for example, from ALSPAC (Avon Longitudinal Study of Parents and Children) data, ${ }^{3}$ in which children in the Avon area who were born between April 1991 and December 1992 have been closely and frequently followed. This data includes a number of different measures of child emotional health at various ages.

\footnotetext{
${ }^{1}$ An alternative, which provides a local estimate of the effect of education, is to appeal to the natural experiment of the raising of the compulsory minimum school leaving age. Oreopoulos and Salvanes (2011) conclude that this directly raised the average happiness of those affected by the change, mainly via the effect of education on income. It is worth noting that this local effect refers to only quite low levels of (compulsory) schooling, and does not inform us the effect of higher education levels on happiness.

${ }^{2}$ See https://www.iser.essex.ac.uk/bhps/.

${ }^{3}$ See http://www.bristol.ac.uk/alspac/.
} 
A second commonly-proposed solution of the satisfaction-education relationship is that education does indeed provide better outcomes for individuals, but also raises their expectations. This is an attractive solution to the mystery. Unfortunately it is nigh-on impossible to test for it in the data sets upon which research in this field typically relies, as we do not believe that these include useful information on individuals' expectations or aspirations. In some broad sense, we would like to know not only how well people do in terms of outcomes, but also how well that they think that they should be doing. It is the gap between these two that will arguably determine the individual's subjective wellbeing outcomes.

We here make some progress regarding expectations using novel data from the Economic and Social Research Institute (ESRI), Cabinet Office of Japan. This data set includes many of the common socio-demographic variables that have been analysed in the literature, as well as self-reported happiness. In this sense, the data set is entirely standard. Where we believe it adds new information to the literature is that respondents are also asked about how happy they think that they should be.

Stutzer (2004) focused on the link between income aspirations and self-reported happiness, finding both that higher income aspirations reduce self-reported happiness, and that higher average income in the community is associated with higher aspired levels of income. We are here along the same lines, but instead of considering expectations with respect to income, house or job, we consider broader expectations over well-being itself. Our hypothesis is that the level of well-being that individuals report will depend on the comparison of the 'pure' level of happiness that the individual feels to her happiness aspirations. Individuals' ideal levels of happiness arguably reflect such aspirations.

That individual aspirations may play a central role in determining self-reported happiness is reasonably commonplace in the subjective well-being literature. Following Gilboa and Schmeidler (2001), individual aspirations can usefully be though thought to be formed in two broad ways. The first is based on social-comparisons theory, whereby individuals often care not only about the absolute level of income (say) that they receive, but also how their income shapes up compared to some group of others. Interpersonal comparisons are argued to affect the individual's level of aspirations (as in Stutzer), as 
seeing that others earn more may lead the individual to aspire to a higher level of income. Equally, adaption (comparisons to oneself in the past) may play a role, in that individuals often seem to become used to any higher level of income. Here, aspirations may rise with the individual's own level of past income: rather than involving a comparison to others, here the individual compares to her own past experience. Aspirations will then track the individual's own income (potentially with a lag).

The second channel proposed by Gilboa and Schmeidler (2001) relies on reasoning, whereby direct information is used to provide a justification for what the individual could or should expect. We can imagine these aspirations referring to all kinds of different aspects of the individual's life: their income, their job, their house etc. One of the few contributions which has been able use direct information on expectations, here with respect to income, is McBride (2010). McBride adopts an experimental approach in which the amount of money that the individual expects to win in a simple matchingpennies game is changed via manipulations (about which the subject is informed) of the playing behaviour of the individual's (computerised) partner. Conditional on both the amount the individual ends up winning, and the amount other players playing the same game win, McBride shows that higher expectations of winnings significantly reduce reported satisfaction.

Long (2005) provides a number of pieces of evidence that the job satisfaction reported by workers in the first wave of HILDA is influenced by expectations. In particular, she is able to proxy job expectations by whether the individual considers themselves fairly paid, and the importance of family, work and other aspects of life to the individual. Education is shown to be negatively correlated with job satisfaction for both men and women. However, the addition of the expectations variables reduces the size of the estimated coefficient on education. Equally, education is shown to be positively correlated with job satisfaction for those who feel that they can use their own skills in their job. The argument is then that education my lower job satisfaction because the educated are less likely to feel that they are able to use their skills.

Perhaps the two papers most closely related to ours (although neither considers the role played by education per se) are Schwandt (2014) and Barazzetta (2014). In the former, direct information on well-being aspirations is obtained in German Socio- 
Economic Panel (SOEP) data by asking individuals how satisfied they think that they will be with their life in five years' time. The comparison of this prediction to the satisfaction that the individuals actually report in this panel data five years later reveals that individual predictions are systematically wrong. These predictions in particular move from an overprediction of satisfaction when young to an underprediction when older, with the author suggesting that the regret from unmet aspirations may lie behind the well-known U-shape between subjective well-being and age.

Barazzetta (2014) is somewhat along the same lines, but refers to income expectations and outcomes in BHPS data. Specifically, BHPS respondents are asked each year whether they think their financial situation will worsen, stay the same or deteriorate over the next year. Equally, they are also asked how their financial situation has changed over the past year. By comparing the expectations of financial situation for time $t$ made at time $t-1$ to the reported change in financial situation between $t-1$ and $t$ reported at time $t$, Barazzetta is able to calculate a 'deviation' variable showing how outcomes relate to the expectations made one year earlier. She shows that this deviation variable is significantly correlated in the expected direction with both life satisfaction and a measure of psychological health, the GHQ.

Our paper is in the spirit of a number of the above contributions. We here demonstrate that certain variables are correlated in the same direction with both selfreported current subjective well-being and well-being aspirations. We concentrate in particular on the role of education in this respect. Higher education is shown to increase both outcomes and expectations, so that its final effect on subjective well-being is muted.

The remainder of this paper is organised as follows. Section 2 briefly reviews the literature related to the relationship between education and subjective well-being. Section 3 then describes the characteristics of our data set and presents the estimation model. Section 4 discusses the empirical results and, last, Section 5 concludes. 


\section{Aspirations, Education and Happiness}

We concentrate in this paper on the empirical relationship between education, on the one hand, and reported and aspired happiness on the other. Previous work has underlined the existence of both direct and indirect effects of education on happiness (see, for example, Castriota, 2006, Cunado and Gracia, 2012, and del Mar SalinasJiménez et al., 2013). The direct effect is that the higher-educated have more selfconfidence, self-esteem and so on than do the lower-educated; there may well also be a direct effect of the acquisition of knowledge itself on subjective well-being. There are three main types of indirect effects. First, better education brings higher incomes and better opportunities on the labour market in general. Second, education is a signal of quality, and the higher-educated obtain indirect well-being from prestige. Third, the more educated on average have better habits and health behaviours.

With regard to existing empirical work, a number of authors find a positive correlation between education and subjective well-being (Di Tella et al., 2001, Easterlin, 2005, Layard, 2005, Albert and Davia, 2005, Becchetti et al., 2006, Castriota, 2006, Oreopoulos, 2007, and Florida et al. 2013). However, other work has concluded that this relationship is actually ambiguous (Veenhoven, 1996, Inglehart and Klingemann, 2000, and Hickson and Dockery, 2008). Layard et al. (2012) find a positive correlation between education and subjective well-being in SOEP and World Values Survey data, but not in the BHPS or the Gallup World Poll.

Early results in Klein and Maher (1966) and Warr (1992) reveal a negative relationship between education and satisfaction. Equally, in both Clark and Oswald (1996) and Clark (1999), the analysis of BHPS data reveals that the higher-educated report lower levels of job satisfaction, ceteris paribus, than do the less-educated. In Blanchflower and Oswald (1998), the respondents in the National Child Development Study with college degrees are the least satisfied with their work. An intriguing recent take on this finding appears two recent pieces of work, by Binder and Coad (2011) on BHPS data, and del Mar Salinas-Jiménez et al. (2014) using two waves of European Social Survey data. In both contributions education and life satisfaction are positively 
correlated at the lower end of the well-being distribution, with this correlation turning negative towards the top end of the well-being distribution.

The proposed explanation for the a priori counter-intuitive result of a zero or negative correlation between subjective well-being and education is that the highereducated likely have higher expectations. We assume here that individual utility depends on the gap between outcomes and aspirations. Education will on the one hand increase aspirations or expectations regarding wages and job quality in general. Of course, it is on average indeed also associated with better labour-market outcomes. The sign of the unconditional correlation between education and happiness will then depend on whether it is aspirations or outcomes which rise the fastest. If aspirations outstrip outcomes, then education will be negatively correlated with happiness; if both rise at the same rate then the unconditional correlation will be zero. It is worth noting that much of the empirical analysis of the relation between subjective well-being and education actually controls for some of the outcome variables that are arguably caused by education (notably income): these are the indirect effects of education on well-being. This will yield a conditional correlation coefficient which is lower than the unconditional coefficient.

We here test the hypothesis that education affects aspirations directly. In particular, we ask whether education is correlated in the same way with self-reported happiness and individual aspirations. This will help us to better understand the relationship between education and happiness.

\section{Data and Model}

Our empirical analysis is based on Japanese cross-section data from the Economic and Social Research Institute (ESRI), Cabinet Office. The sample covers 6,236 (47\% male and 53\% female) Japanese respondents in early 2013. In the questionnaire, individuals are asked about both their current level of happiness and about how happy they wish to be. The wording of these happiness questions is as follows: "Currently, how happy do you feel? Score the degree of your happiness between 10 (very happy) 
and 0 (very unhappy)"; and "What is your desired condition, where 10 is very happy and 0 is very unhappy". The mean of these two happiness variables for men are 6.6 and 8.2 respectively, and for women 6.8 and 8.4. Around thirty per cent of individuals are as happy as they wish to be (in the sense that their two happiness scores coincide), and 65 per cent of individuals are less happy than they wish to be. This leaves just 6 per cent who are 'too happy' in this sense. When differences exist between actual and ideal happiness, they are most often of one or two points on the zero to ten scale. The full distribution of ideal minus actual happiness is illustrated in Figure 1.

[Figure 1 about here]

With respect to education, respondents' highest educational attainment is captured by a number of dummy variables: junior high school (junior high school graduates or high-school dropouts); high school (high-school graduates, 2-year college dropouts or 4-year college dropouts); 2-year college (vocational, junior or technical junior college graduates); university (4-year college graduates and graduate dropouts); and graduateschool graduates. Figures 2 and 3 show the relationship between actual and ideal happiness, on the one hand, and education on the other. Both actual and ideal happiness rise with education for men; for women there is something of a downturn for those with postgraduate qualifications, although the cell size is small here, and this drop could simply represent sample variability.

[Figure 2 about here]

[Figure 3 about here] 
The satisfaction scores differ significantly by sex, with women reporting higher scores for both satisfaction measures (see Nolen-Hoeksema and Rusting, 1999). As intimated in Figures 2 and 3, this difference is particularly sharp at the 2-year college and university education levels. Our regression analysis below will be split by sex.

The data also includes other personal characteristics such as age, marital status, income, ${ }^{4}$ labour-force status, number of children, ${ }^{5}$ and region of residence. These will be introduced as control variables when we carry out regression analysis of the two happiness measures. The definitions of these different variables appear in Table 1, with descriptive statistics in Table 2. The actual questionnaire items are listed in Appendix A.

[Table 1 about here]

[Table 2 about here]

The two tables in Appendix B present the correlation matrices between all of our variables, separately for men and women. The correlation coefficient between actual happiness and ideal happiness turns out to be very similar for men (0.47) and women (0.48).

The main idea to which we appeal is that, in line with a great deal of work across the social sciences, individuals' reported happiness levels will reflect the gap between what they receive (their outcome) and their aspirations or expectations. For an individual $i$ we denote reported happiness by $\mathrm{H}_{\mathrm{Ri}}$, and the aspired level of happiness by $\mathrm{H}_{\mathrm{Ai}}$. The 'pure' level of happiness (before individual $i$ 's comparison of outcomes to aspirations) can be

\footnotetext{
${ }^{4}$ Gross annual income is measured on a twelve-point scale. We use the median value of each category in order to convert the answers into a continuous variable. We use a value of $20 \mathrm{M}$ Yen for the last openended 15M Yen or over category, as is common in Japan.

${ }^{5} \mathrm{We}$ will introduce children as a simple binary variable for 'has any children'. Introducing more detailed categories including the number of children did not add any strong insights (there was something of a positive correlation with both happiness measures for women having three or more children).
} 
denoted by $\mathrm{H}_{\mathrm{Pi}}$. Both of $\mathrm{H}_{\mathrm{Pi}}$ and $\mathrm{H}_{\mathrm{Ai}}$ will likely depend on some explanatory variables, $\underline{X_{i}}$. We can then imagine a relationship of the form

$$
\mathrm{H}_{\mathrm{Ri}}=\mathrm{f}\left(\mathrm{H}_{\mathrm{Pi}}\left(\underline{X}_{\mathrm{i}}\right)-\mathrm{H}_{\mathrm{Ai}}\left(\underline{X}_{\mathrm{i}}\right)\right)
$$

Many surveys contain what are now becoming standard subjective well-being questions: these can be thought of as providing some measure of $\mathrm{H}_{\mathrm{Ri}}$. These variables are then used as dependent variables in regressions, relating them to some set of explanatory variables, $\underline{X}_{i}$. The above equation makes clear that an insignificant relationship between $H_{R}$ and some variable $X_{1}$, say, can actually reflect two very different scenarios.

1) The variable $X_{1}$ has no effect on either pure and aspired well-being: $d H_{P} / d X_{1}=0$ and $\mathrm{dH}_{\mathrm{A}} / \mathrm{dX}_{1}=0$.

2) The variable $X_{1}$ does affect pure well-being, but its effect is cancelled out by changing aspirations: $\mathrm{dH}_{\mathrm{P}} / \mathrm{dX}_{1}=\mathrm{dH}_{\mathrm{A}} / \mathrm{dX}_{1}$, so that $\mathrm{dH}_{\mathrm{R}} / \mathrm{dX}_{1}=0$

This second scenario is often mentioned in order to understand the relationship between education and subjective well-being. ${ }^{6}$ Education raises income, and is associated with many other positive outcomes, as noted above. However, it may well also raise expectations or aspirations about what the individual should receive. This explains why, when we control for income, the estimated coefficient on education in a well-being regression is sometimes negative.

We consider the relationship between our two happiness measures and the explanatory variables using both OLS and ordered probit estimation. In the latter case, let the outcome $Y_{i}$ be the happiness measures, i.e. $Y \in\{0,1, \ldots, 10\}$. Assume that $Y_{i}$ is generated by the unobserved latent variable, $Y^{*}, \beta$ is a set of parameters to be estimated, and $\varepsilon$ is a random error with mean zero and variance $\sigma^{2}$ :

$$
Y_{i}^{*}=\beta^{\prime} x_{\mathrm{i}}+\varepsilon_{i}
$$

\footnotetext{
${ }^{6}$ See in particular Ferrante (2009), who produces some evidence consistent with this hypothesis for both education and perceived opportunities.
} 
With a continuous latent variable $\mathrm{Y}^{*}$, with $\mu$ being the estimated threshold values, we have the following.

$$
\begin{gathered}
Y_{i}=0 \text { if } Y^{*} \leq \mu_{1} \\
Y_{i}=1 \text { if } \mu_{1}<Y^{*} \leq \mu_{2} \\
\vdots \\
Y_{i}=10 \text { if } \mu_{10}<Y^{*}
\end{gathered}
$$

The probabilities of observing the outcomes are given by:

$$
\begin{aligned}
& \operatorname{Pr}\left(Y_{i}=0\right)=\operatorname{Pr}\left(Y^{*} \leq \mu_{1}\right)=\operatorname{Pr}\left(\beta^{\prime} x_{\mathrm{i}}+\varepsilon_{i} \leq \mu_{1}\right)=\varphi\left(\mu_{1}-\beta^{\prime} x_{\mathrm{i}}\right) \\
& \operatorname{Pr}\left(Y_{i}=1\right)=\operatorname{Pr}\left(\mu_{1}<Y^{*} \leq \mu_{2}\right)=\varphi\left(\mu_{2}-\beta^{\prime} x_{\mathrm{i}}\right)-\varphi\left(\mu_{1}-\beta^{\prime} x_{\mathrm{i}}\right) \\
& \quad \vdots \\
& \operatorname{Pr}\left(Y_{i}=10\right)=\operatorname{Pr}\left(\mu_{10}<Y^{*}\right)=\operatorname{Pr}\left(\beta^{\prime} x_{\mathrm{i}}+\varepsilon_{i}<\mu_{10}\right)=1-\varphi\left(\mu_{10}-\beta^{\prime} x_{\mathrm{i}}\right)
\end{aligned}
$$

where $\varphi($.$) is the univariate standard normal cumulative distribution function.$

The following section describes the results of these various estimations.

\section{Results}

The results from the main part of our analysis appear in Tables 3 and 4. We carry out both OLS and ordered probit estimation, although the choice of estimation method makes only little difference to the results (see Ferrer-i-Carbonell and Frijters, 2004, and Clark, 2015). ${ }^{7}$ The advantage of the former is that the coefficients are the marginal effects, which makes comparisons across equations simpler.

\footnotetext{
${ }^{7}$ Although it is worth pointing out that the equivalence in Ferrer-i-Carbonell and Frijters (2004) is established using panel data, and we are here working with a cross-section. In Section 5 of Clark (2015),
} 
The first and third columns in both of these tables show what is by now a fairly standard set of results relating actual happiness to a set of socio-demographic variables. Many of the results in Tables 3 and 4 are well-known for both males and females. Happiness is U-shaped in age, with a minimum in the early 50s (Clark et al., 1996). Education in Japan is strongly positively correlated with happiness, even controlling for the level of income. ${ }^{8}$ Existing work on Western countries often finds insignificant or even negative correlations (see Layard et al., 2012), although recent work on income satisfaction in Japan also uncovered positive education coefficients (Clark et al., 2013). This strong correlation of education with subjective well-being, even when controlling for income, may therefore be something of a Japanese specificity as compared to other OECD countries, and doubtless merits further investigation.

In the other results referring to actual happiness in Tables 3 and 4, marriage attracts a positive estimated coefficient in this cross-section data, as does the log of income. Last, the estimated coefficients on labour-force status reveal that those in education (the omitted category) report the highest levels of actual happiness. The estimated coefficients on employment are only slightly more positive than those on being out of work. This is consistent with the results in Sano and Ohtake (2007), who use Japanese panel data. It is worth mentioning that we are holding income constant in this regression, so that the coefficient on employment might be thought to just trace out the marginal value of leisure. The estimated coefficient on housework is especially large and negative for men; retirement equally is associated with sharply lower levels of subjective well-being for men, but much less so for women.

the estimated coefficients from the estimation of subjective well-being in BHPS data by ordered probit and OLS were correlated at over 0.98. This held for all four measures considered (Caseness GHQ-12, life satisfaction, vitality and resilience). We here find the same kind of results. If we compare the estimated coefficients in a given column of Table 3 to their equivalents in Table 4, we obtain correlation coefficients of over 0.99 for all four columns. This suggests that the function we are estimating is pretty much linear. As pointed out by Mavromaras et al. (2012), it is more difficult to eliminate hidden common factor interpretations in cross-section than in panel data. This drawback applies to our work here, although in terms of our research question we would require any such factor to be systematically correlated with not only education and reported happiness, but also with ideal happiness as well.

${ }^{8}$ We can also estimate these happiness equations dropping variables that we think might be partially caused by education (income, labour-force status, marital status and number of children). This produces estimated coefficients on actual happiness that are some $20 \%$ higher for university education and above for men, but not much change in the other education coefficients. 
[Table 3 about here]

[Table 4 about here]

Our main interest in this analysis is not the estimated coefficients in columns (1) and (3) on 'Actual happiness' as such, but rather the relationship of these to their counterparts in columns (2) and (4), where we consider an analogous regression for 'Ideal happiness'. The coefficients in this second regression show which variables are correlated with how happy the individual would ideally like to be. We argue that this is analogous to a regression of $\mathrm{H}_{\mathrm{A}}$ in our model above. The results show that the patterns in desired happiness broadly reflect those in reported happiness. The comparison of the two estimated coefficients then allows us to calculate what the pure 'non-dampened' relationship between the explanatory variables and subjective well-being would be were there to be no change in aspirations.

Comparing the determinants of actual and ideal happiness, the coefficients on age are negative and statistically significant in both sets of estimation results. Equally, the estimated coefficients on single and divorced are negative and significant for both outcome measures, being associated with both actual and ideal happiness. Both actual and ideal happiness increase with education (although, again, not significantly so for 'graduate' for women). It is in particular notable that the level of ideal happiness is higher amongst the highly-educated relative to the relatively less-educated. This finding could be considered as providing support for the argument developed in Clark (1999), that the lower-educated report higher levels of job satisfaction than do the highereducated in part due to their lower expectations. In our regression results, education does lead to higher reported happiness, but with an effect that would have been twice as large or more had aspirations not risen at the same time.

We can see the same broad type of result for the income variable: this is associated with both higher actual and desired happiness. Evidence from the Minimum Income Qustion (Stutzer, 2004) and more generally from the Leyden Welfare Function of 
Income has suggested that income and education may well act to raise aspirations (see van Praag, 1971, and van Praag and Kapteyn, 1973). ${ }^{9}$ The argument is analogous to that proposed for education. Income is associated with greater reported well-being in the cross-section, but the correlation would have been even higher had aspirations not risen at the same time.

With regard to labour-force status, the estimated coefficients in the actual and ideal happiness always agree with each other. According to our interpretation, the correlation between labour-force status and pure happiness $\left(\mathrm{H}_{\mathrm{P}}\right)$ is then larger than that revealed in the actual happiness regressions. In the OLS regressions in Table 4, we can calculate the pure effect as the sum of the estimated coefficients in the actual and ideal happiness regressions. This calculation reveals that the worst labour-force status (holding income constant) is housework, followed by unemployment for men. For women, it is rather unemployment, with housework being ranked as somewhat better than working.

Last, we include region dummies in our estimations. The control group here is the 'Kanto' region, which includes the Tokyo metropolis and ten prefectures. The 'Tohoku' region attracts the lowest estimated coefficient for actual happiness for men, and for both actual and ideal happiness for women.

Overall, the effect of education and employment is similar in sign, size and significance across the two happiness measures. As such, our reading is that the correlation between 'pure' subjective well-being and these two variables is twice as large as that which is revealed the reported level of subjective well-being; the other half is attenuated by changes in aspirations. ${ }^{10}$ With respect to marital status and income, the coefficient in the ideal happiness equation is smaller than that in the reported happiness

\footnotetext{
${ }^{9}$ In Income Evaluation Questions, individuals provide income levels corresponding to different verbal labels. In one of the Swiss datasets in Stutzer (2004), income aspirations are measured by the answer to the question "What income would you indicate as good or bad in your circumstances? Please try to state what income per month (before taxes) for your entire household you consider to be [. . ] sufficient". The Minimum Income Question, which appears in both of Stutzer's Swiss datasets, is of the same nature: "What household income per month would you consider an absolute minimum in order to make ends meet and without running into debt even if you reduce your needs to a minimum?"

${ }^{10}$ We have experimented with a number of different specifications here. In one, we included the log of household income, as well as individual income. In another, we estimated actual and ideal happiness jointly in a SUR estimation, dropping the region dummies in the ideal happiness regression. The results (available upon request) were very similar in both of these new specifications.
} 
equation. There is therefore still some attenuation, but it is much smaller in size than that with respect to education.

We can also split the sample according to the comparison of actual and ideal happiness. The left hand panel of Table 5 models the probability of being less happy than you would like to be (i.e. $\mathrm{H}_{\mathrm{R}}<\mathrm{H}_{\mathrm{A}}$ ) while the right-hand panel models the probability of being 'too happy'. The effect of age is consistent, being hump-shaped for being less happy than you wish to be, and U-shaped for too happy. Marital status only matters for being less happy than you wish to be, and income only plays a significant role for women.

Of most interest here are the estimated education coefficients. We can see that it is university education that is the culprit here, being significantly positively (negatively) correlated with the probability of being less happy than you would like to be (too happy). The estimated coefficients on post-graduate degrees are of the same shape, but are not significant (probably due to smaller cell sizes).

[Table 5 about here]

We may finally wonder whether the results are different for those who currently 'use' their education (and so drop those currently in education, in housework or retired). The regression results for these male 'education users' are very similar to those in the whole sample (perhaps unsurprisingly), with the estimated education coefficients in both happiness regressions changing in size by less than 10\% For women, the coefficients do move around more, in some cases by up to $50 \%$. However, the ratio of the education coefficient in the actual happiness to that in the ideal happiness regression (which tells us about the deflation effect of changing aspirations) is remarkably robust for both men and women, moving by less than $15 \%$ in all cases. 


\section{Conclusion}

This paper has used novel Japanese cross-section data including information on both actual happiness and the individual's ideal level of happiness. The main idea put forward here is that the individual's reported level of happiness will reflect the gap between what they actually receive and what they expected to receive. We estimate both reported happiness and happiness-aspirations equations, and the OLS and Ordered Probits yield very similar results. We find in particular that education leads to both higher reported happiness and desired happiness. This suggests that a significant part of the happiness effect of education is cancelled out by higher aspirations: education then does raise actual happiness but also raises expectations or aspirations about what the individual should receive. The same pattern of results is found for income, although the happiness attenuation effect here is smaller. We believe that these regression results underline the importance of changing aspiration levels in determining individual subjective well-being.

Our results do come from one country at one point in time. Japan is in a sense not a typical country in terms of subjective well-being, with low job satisfaction scores (Sousa-Poza and Sousa-Poza, 2000) and life satisfaction scores that are notably below those that its objective characteristics would predict (Abdallah et al., 2008). In addition, Japan in 2013 was in a recessionary period, which could have had a particular effect on either actual or aspired happiness. In particular, the relative lack of jobs for life, or at least satisfying jobs for life during recessions, might be reflected in a greater mismatch with education. The specific analysis of this point would require either cross-country data or time-series data within Japan, neither of are currently available as far as we know.

Japan is also dissimilar to some other countries in a number of other ways, including in terms of education and employment. In particular, Japan has very strong employment protection making it quite difficult to dismiss regular employees (Kambayashi, 2008, Ohtake et al., 2004, and Okudaira et al., 2013). Once Japanese workers find a satisfactory position, they can usually remain in that position until retirement (although this may be somewhat less the case during the recessions of recent years). Those with higher education are more likely to find such satisfying and secure positions. In our 
terminology, it is then unsurprising that education and pure happiness, $\mathrm{H}_{\mathrm{P}}$, be positively correlated. This positive correlation could be larger in Japan (and other similar Asian countries) than in countries where good jobs are allocated less with respect to education and ability, and more with respect to some other criteria (such as social class).

At the same time, education likely affects the aspired level of happiness $\left(\mathrm{H}_{\mathrm{A}}\right)$ as well. We argued above that it was the comparison of $\mathrm{H}_{\mathrm{P}}$ to $\mathrm{H}_{\mathrm{A}}$ that determined reported happiness scores. The fact that education is positively correlated with reported happiness suggests that $H_{P}$ rises more with education in Japan than does $\mathrm{H}_{\mathrm{A}}$ (and of course does not necessarily mean that there is no effect of education on aspired happiness in Japan). In other countries, where the aspiration effect is larger, or the outcome effect is smaller, these two terms may cancel each other out, so that there is no net effect of education on reported happiness. The worst possible world would be one where education raises hopes for the future (aspired happiness) but does not deliver on these promises. ${ }^{11}$ Here we will see education and happiness being negatively correlated. We think that this scenario is unlikely in Asia, but may well hold in other countries.

${ }^{11}$ See Duru-Bellat (2006) for the phenomenon of educational inflation in France. 


\section{Figure 1. Ideal Happiness minus Actual Happiness.}

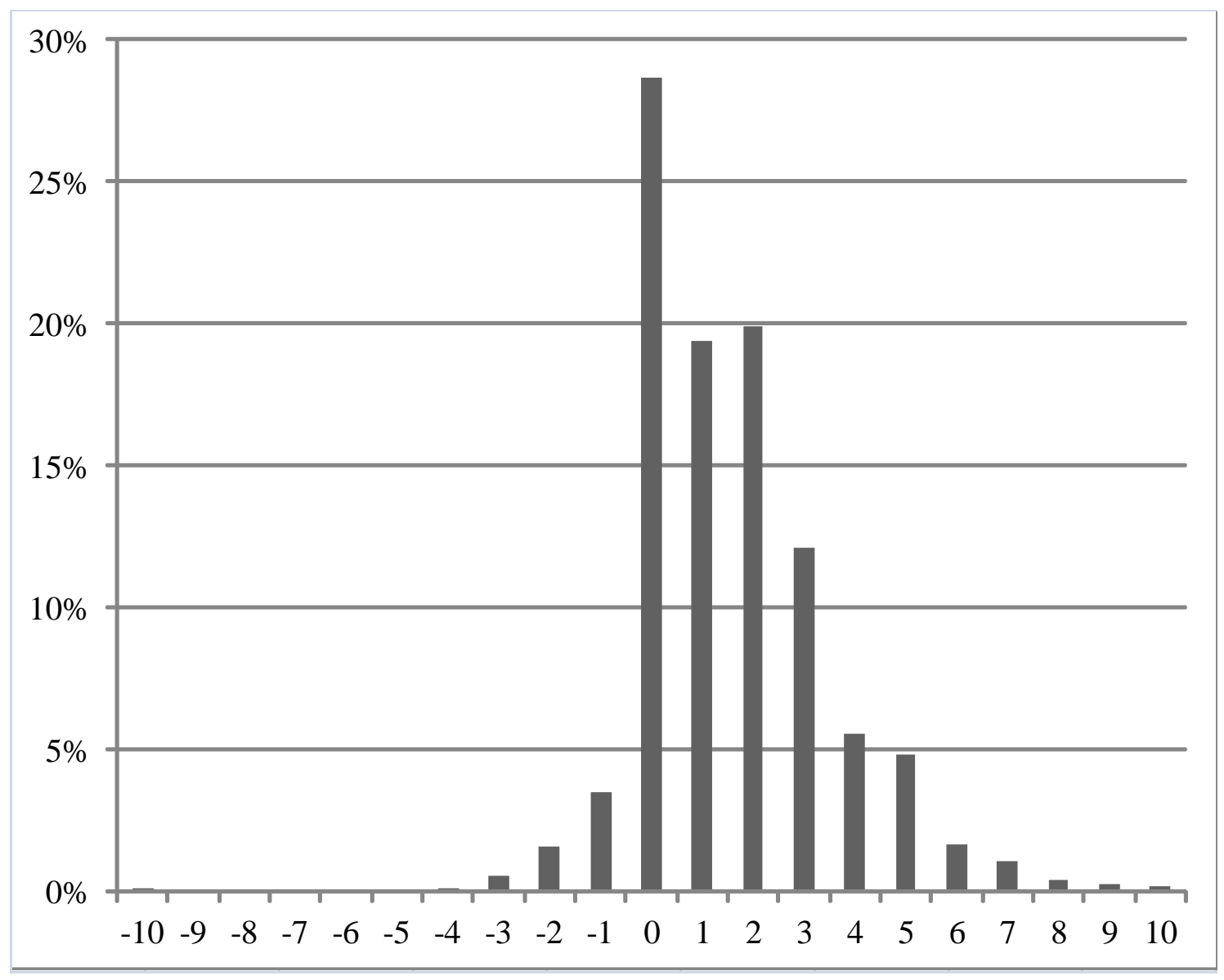

Note: Both ideal and actual happiness are measured on zero to ten scales, with higher numbers indicating greater happiness. In the graph, those with a positive value of ideal happiness minus actual happiness are less happy than they would ideally like to be; the far fewer individuals with negative values in the graph are 'too happy'. 
Figure 2. Education and Happiness: Men

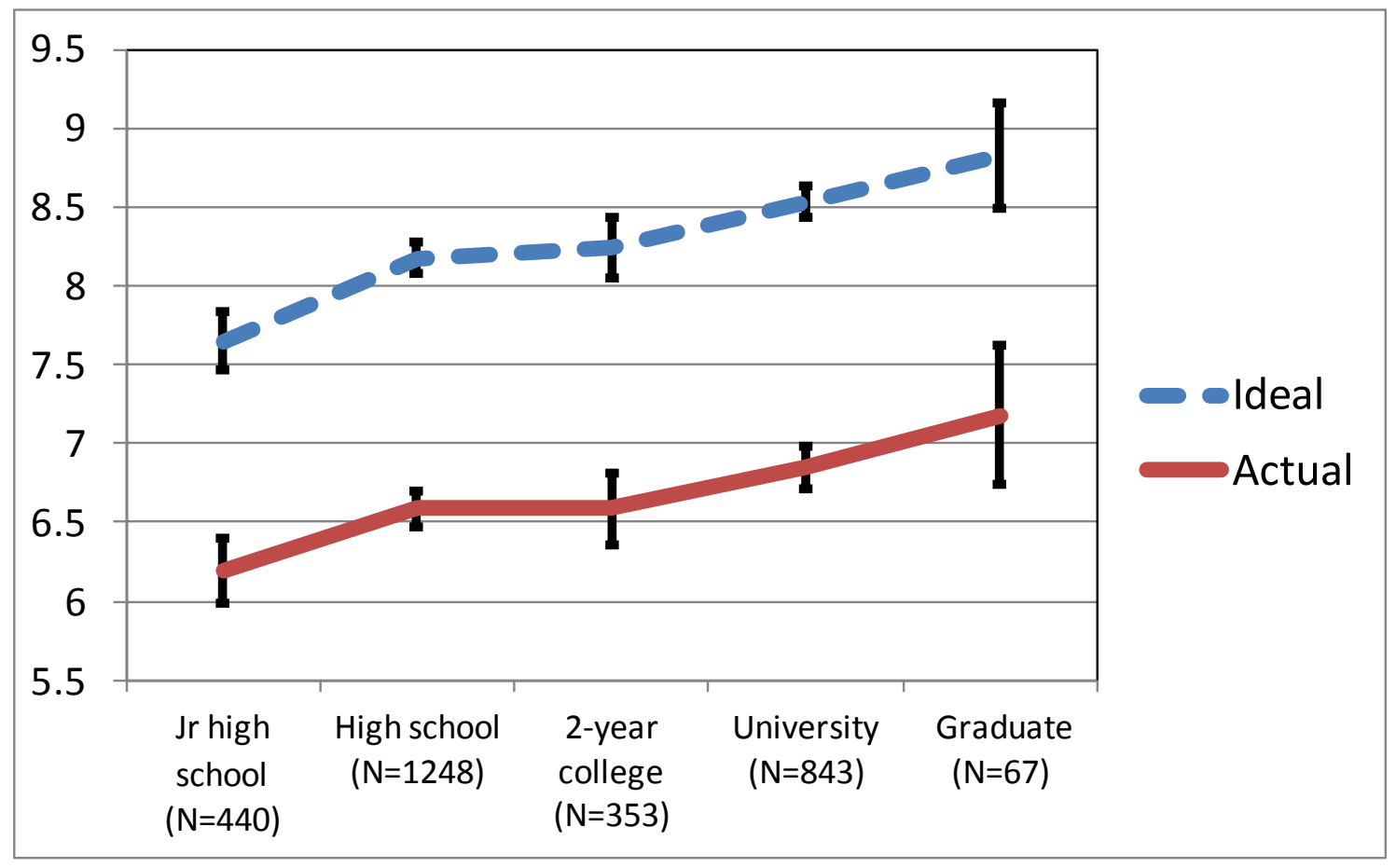

Figure 3. Education and Happiness: Women

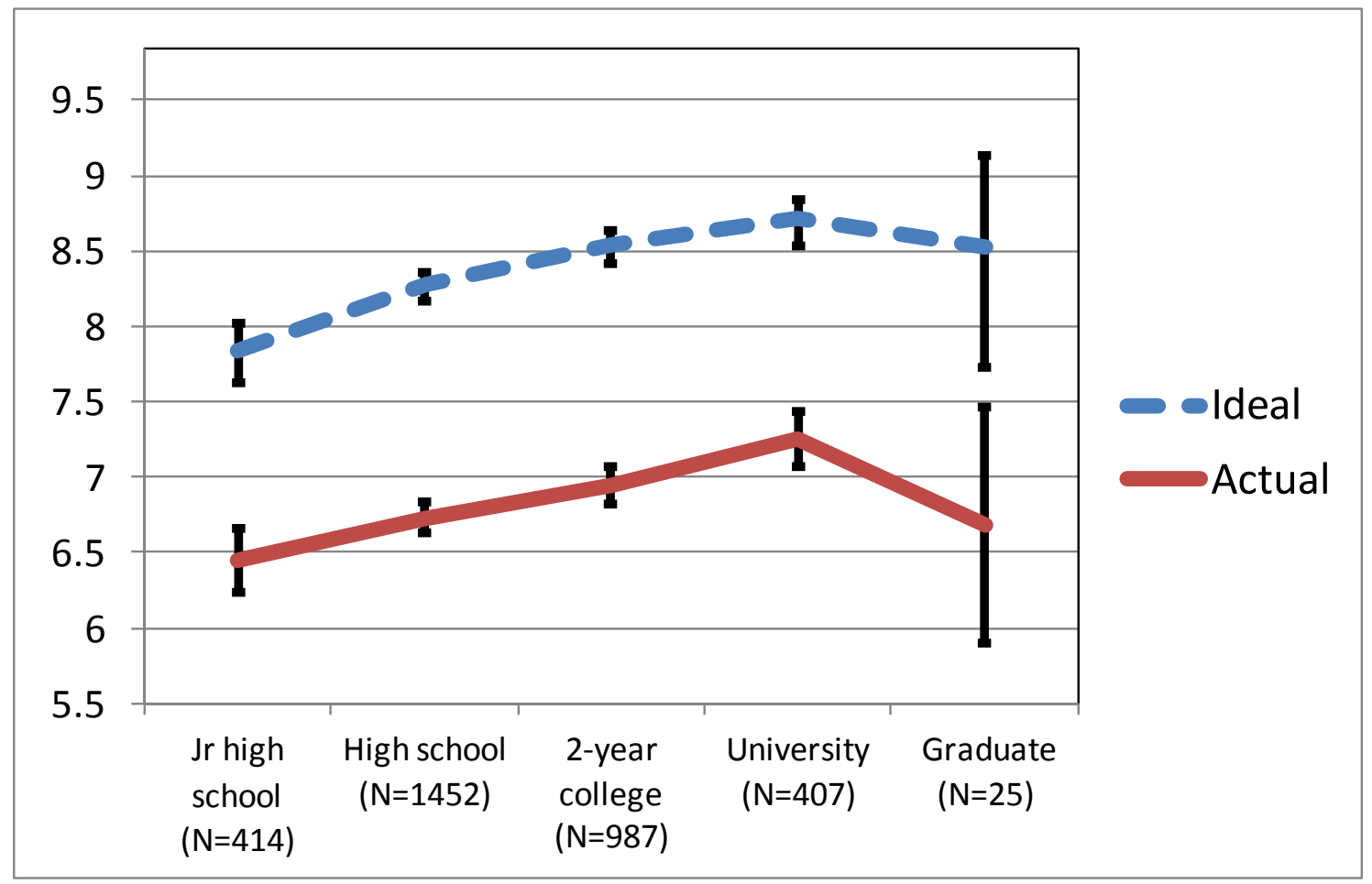

Note: The vertical bars represent the $95 \%$ confidence intervals in both figures. 


\section{Table 1. Variable Definitions}

\begin{tabular}{|c|c|}
\hline Variables & Definition \\
\hline Actual happiness & Currently how happy are you, from 0 (very unhappy) to 10 (very happy). \\
\hline Ideal happiness & What is your desired condition, from 0 (very unhappy) to 10 (very happy). \\
\hline Age & Age of the respondent in years. \\
\hline Marital status & Dummy variables for the respondent being single, married, divorced, widowed \\
\hline lnIncome & Natural log of annual gross income (based on a 12-level categorical variable). \\
\hline Educational level & Dummy variables for the respondent's highest educational qualification: \\
\hline Employment status & $\begin{array}{l}\text { Junior high school, High school, 2-year college, University, Graduate. } \\
\text { Dummy variables for the respondent being in permanent employment, } \\
\text { temporary employment, board member, self-employed, out of work, } \\
\text { retired, doing housework and in education. }\end{array}$ \\
\hline No children & Dummy variable for the respondent having no children. \\
\hline Region & Japanese region of residence. \\
\hline
\end{tabular}

Note: In employment status, "board member" refers to individuals in senior management positions (senior executives or directors). 
Table 2. Descriptive Statistics

\begin{tabular}{|c|c|c|c|c|}
\hline \multirow[t]{2}{*}{ Variable } & \multicolumn{2}{|c|}{ Male } & \multicolumn{2}{|c|}{ Female } \\
\hline & Mean & Std. Dev. & Mean & Std. Dev. \\
\hline Actual happiness & 6.62 & 2.08 & 6.83 & 2.02 \\
\hline Ideal happiness & 8.22 & 1.74 & 8.36 & 1.62 \\
\hline Age & 47.79 & 17.82 & 46.89 & 17.30 \\
\hline Age-squared/1000 & 2.60 & 1.72 & 2.50 & 1.67 \\
\hline Married & 0.70 & 0.46 & 0.67 & 0.47 \\
\hline Single & 0.26 & 0.44 & 0.24 & 0.43 \\
\hline Divorced & 0.02 & 0.15 & 0.04 & 0.19 \\
\hline Widowed & 0.01 & 0.11 & 0.05 & 0.22 \\
\hline lnIncome & 5.28 & 1.74 & 3.89 & 2.06 \\
\hline Edu: Junior high school & 0.15 & 0.36 & 0.13 & 0.33 \\
\hline Edu: High school & 0.42 & 0.49 & 0.44 & 0.50 \\
\hline Edu: 2-year college & 0.12 & 0.32 & 0.30 & 0.46 \\
\hline Edu: University & 0.29 & 0.45 & 0.12 & 0.33 \\
\hline Edu: Graduate & 0.02 & 0.15 & 0.01 & 0.09 \\
\hline Permanent employment & 0.54 & 0.50 & 0.44 & 0.50 \\
\hline Temporary employment & 0.08 & 0.27 & 0.16 & 0.36 \\
\hline Board member & 0.06 & 0.23 & 0.02 & 0.14 \\
\hline Self-employment & 0.10 & 0.30 & 0.02 & 0.15 \\
\hline Out of work & 0.06 & 0.24 & 0.06 & 0.24 \\
\hline Retired & 0.11 & 0.31 & 0.07 & 0.26 \\
\hline Housework & 0.00 & 0.07 & 0.18 & 0.39 \\
\hline In education & 0.05 & 0.22 & 0.04 & 0.21 \\
\hline No child & 0.32 & 0.47 & 0.29 & 0.46 \\
\hline Hokkaido & 0.04 & 0.20 & 0.04 & 0.20 \\
\hline Tohoku & 0.09 & 0.29 & 0.09 & 0.29 \\
\hline Kanto & 0.31 & 0.46 & 0.30 & 0.46 \\
\hline Hokuriku-Tohsan & 0.10 & 0.30 & 0.09 & 0.29 \\
\hline Tokai & 0.13 & 0.33 & 0.12 & 0.33 \\
\hline Kinki & 0.14 & 0.35 & 0.15 & 0.35 \\
\hline Chugoku-Shikoku & 0.09 & 0.29 & 0.09 & 0.28 \\
\hline Kyushu-Okinawa & 0.10 & 0.30 & 0.11 & 0.32 \\
\hline
\end{tabular}

Note: Male $(\mathrm{N}=2951)$, Female $(\mathrm{N}=3285)$. 
Table 3. Ordered Probit Regressions: Actual and Ideal Happiness

\begin{tabular}{|c|c|c|c|c|}
\hline & \multicolumn{2}{|c|}{ Male } & \multicolumn{2}{|c|}{ Female } \\
\hline & Actual & Ideal & Actual & Ideal \\
\hline Age & $-0.074 * * *$ & $-0.022 * *$ & $-0.044 * * *$ & $-0.016 *$ \\
\hline Age-squared/1000 & $0.627 * * *$ & 0.053 & $0.359 * * *$ & 0.004 \\
\hline Single & $-0.929 * * *$ & $-0.422 * * *$ & $-0.456 * * *$ & $-0.311 * * *$ \\
\hline Divorced & $-0.775 * * *$ & $-0.534 * * *$ & $-0.447 * * *$ & $-0.191 *$ \\
\hline Widowed & $-0.536 * * *$ & -0.148 & $-0.229 * *$ & -0.075 \\
\hline lnIncome & $0.087^{* * *}$ & $0.050 * *$ & $0.048 * * *$ & $0.027 * *$ \\
\hline Edu: High school & $0.230 * * *$ & $0.280 * * *$ & $0.226 * * *$ & $0.253 * * *$ \\
\hline Edu: 2-year college & $0.249 * * *$ & $0.317 * * *$ & $0.344 * * *$ & $0.380 * * *$ \\
\hline Edu: University & $0.305 * * *$ & $0.467 * * *$ & $0.505 * * *$ & $0.485 * * *$ \\
\hline Edu: Graduate & $0.446 * * *$ & $0.603 * * *$ & 0.156 & 0.298 \\
\hline Permanent employment & $-0.598 * * *$ & $-0.486 * * *$ & $-0.434 * * *$ & $-0.307 * *$ \\
\hline Temporary employment & $-0.681 * * *$ & $-0.426 * * *$ & $-0.380 * * *$ & $-0.312 * *$ \\
\hline Board member & $-0.391 * *$ & $-0.384 * *$ & -0.145 & -0.277 \\
\hline Self-employment & $-0.538 * * *$ & $-0.419 * * *$ & $-0.333 *$ & -0.156 \\
\hline Out of work & $-0.643 * * *$ & $-0.453 * * *$ & $-0.491 * * *$ & $-0.396 * * *$ \\
\hline Retired & $-0.598 * * *$ & $-0.315 * *$ & $-0.245^{*}$ & -0.087 \\
\hline Housework & $-0.748 * *$ & $-0.698 * *$ & -0.182 & -0.205 \\
\hline No child & 0.050 & 0.009 & -0.098 & -0.116 \\
\hline Hokkaido & -0.031 & -0.085 & 0.017 & 0.101 \\
\hline Tohoku & $-0.146 * *$ & -0.100 & $-0.257 * * *$ & $-0.154 * *$ \\
\hline Hokuriku-Tohsan & 0.087 & -0.009 & 0.049 & 0.039 \\
\hline Tokai & -0.011 & -0.078 & 0.066 & -0.045 \\
\hline Kinki & 0.022 & 0.023 & -0.011 & 0.049 \\
\hline Chugoku-Shikoku & -0.045 & -0.020 & -0.011 & -0.051 \\
\hline Kyushu-Okinawa & 0.070 & 0.004 & 0.038 & 0.035 \\
\hline Log pseudo-likelihood & -5859.7 & -4947.4 & -6533.3 & -5370.7 \\
\hline Sample size & 2951 & 2951 & 3285 & 3285 \\
\hline
\end{tabular}

Note : Significance levels: ${ }^{* * *} \mathrm{p}<0.01,{ }^{* *} \mathrm{p}<0.05,{ }^{*} \mathrm{p}<0.1$. 
Table 4. OLS Regressions:

\section{Actual and Ideal Happiness}

\begin{tabular}{|c|c|c|c|c|}
\hline & \multicolumn{2}{|c|}{ Male } & \multicolumn{2}{|c|}{ Female } \\
\hline & Actual & Ideal & Actual & Ideal \\
\hline$\overline{\text { Age }}$ & $-0.141 * * *$ & $-0.030 * *$ & $-0.086^{* * *}$ & -0.021 \\
\hline Age-squared/1000 & $1.204 * * *$ & 0.050 & $0.696 * * *$ & -0.007 \\
\hline Single & $-1.790 * * *$ & $-0.654 * * *$ & $-0.897 * * *$ & $-0.452 * * *$ \\
\hline Divorced & $-1.496 * * *$ & $-0.850 * * *$ & $-0.923 * * *$ & $-0.353 * *$ \\
\hline Widowed & $-1.036^{* * *}$ & -0.276 & $-0.456 * *$ & -0.175 \\
\hline lnIncome & $0.176^{* * *}$ & $0.086 * *$ & $0.095 * * *$ & $0.044 * *$ \\
\hline Edu: High school & $0.450 * * *$ & $0.496 * * *$ & $0.461 * * *$ & $0.445 * * *$ \\
\hline Edu: 2-year college & $0.480 * * *$ & $0.538 * * *$ & $0.690 * * *$ & $0.661 * * *$ \\
\hline Edu: University & $0.607 * * *$ & $0.827 * * *$ & $0.998 * * *$ & $0.807 * * *$ \\
\hline Edu: Graduate & $0.882 * * *$ & $0.982 * * *$ & 0.315 & $0.537 *$ \\
\hline Permanent employment & $-1.217 * * *$ & $-0.863 * * *$ & $-0.852 * * *$ & $-0.547 * * *$ \\
\hline Temporary employment & $-1.367 * * *$ & $-0.749 * * *$ & $-0.758 * * *$ & $-0.567 * * *$ \\
\hline Board member & $-0.817 * *$ & $-0.686^{* *}$ & -0.339 & $-0.508 *$ \\
\hline Self-employment & $-1.094 * * *$ & $-0.741 * * *$ & $-0.670 * *$ & -0.334 \\
\hline Out of work & $-1.304 * * *$ & $-0.831^{* * *}$ & $-0.995 * * *$ & $-0.730 * * *$ \\
\hline Retired & $-1.209 * * *$ & $-0.587^{* *}$ & $-0.493 *$ & -0.183 \\
\hline Housework & $-1.452 * *$ & $-1.242 * *$ & $-0.384 *$ & $-0.417 * *$ \\
\hline No child & 0.119 & 0.037 & -0.175 & -0.188 \\
\hline Hokkaido & -0.038 & -0.135 & 0.018 & 0.119 \\
\hline Tohoku & $-0.283 * *$ & -0.175 & $-0.510 * * *$ & $-0.231 * *$ \\
\hline Hokuriku-Tohsan & 0.171 & -0.005 & 0.074 & 0.069 \\
\hline Tokai & -0.039 & -0.157 & 0.111 & -0.075 \\
\hline Kinki & 0.049 & 0.019 & -0.024 & 0.080 \\
\hline Chugoku-Shikoku & -0.103 & -0.064 & -0.021 & -0.083 \\
\hline Kyushu-Okinawa & 0.113 & -0.030 & 0.064 & 0.046 \\
\hline Constant & $10.470 * * *$ & $9.509 * * *$ & $9.250 * * *$ & $9.372 * * *$ \\
\hline$\overline{\text { Adjusted } \mathrm{R}^{2}}$ & 0.118 & 0.076 & 0.058 & 0.062 \\
\hline Sample size & 2951 & 2951 & 3285 & 3285 \\
\hline
\end{tabular}


Table 5. Probit Regressions on Actual minus Ideal Happiness

\begin{tabular}{|c|c|c|c|c|}
\hline & \multicolumn{2}{|c|}{ Actual < Ideal } & \multicolumn{2}{|c|}{ Actual > Ideal } \\
\hline & Male & Female & Male & Femal \\
\hline$\overline{\text { Age }}$ & $0.074^{* * * *}$ & 0.030 *** & $-0.039 * *$ & -0.025 \\
\hline Age-squared/1000 & $-0.759 * * *$ & $-0.330 * * *$ & $0.386^{* * *}$ & 0.251 \\
\hline Single & $0.493 * * *$ & 0.107 & -0.193 & -0.165 \\
\hline Divorced & 0.182 & -0.013 & -0.368 & 0.050 \\
\hline Widowed & $0.669^{* * *}$ & 0.063 & 0.064 & -0.212 \\
\hline lnIncome & -0.042 & $-0.033 * *$ & 0.041 & 0.065 \\
\hline Edu: High school & -0.006 & 0.031 & $-0.202 *$ & -0.061 \\
\hline Edu: 2-year college & -0.050 & 0.022 & -0.136 & -0.090 \\
\hline Edu: University & $0.188^{* *}$ & 0.013 & $-0.271 * *$ & -0.296 \\
\hline Edu: Graduate & 0.181 & 0.235 & -0.347 & -0.253 \\
\hline Permanent employment & -0.062 & 0.218 & 0.015 & -0.303 \\
\hline Temporary employment & 0.178 & 0.089 & 0.011 & -0.056 \\
\hline Board member & -0.258 & -0.230 & -0.229 & -0.115 \\
\hline Self-employment & -0.068 & 0.217 & 0.048 & -0.524 \\
\hline Out of work & -0.125 & 0.071 & 0.264 & 0.057 \\
\hline Retired & 0.178 & 0.091 & 0.014 & -0.086 \\
\hline Housework & -0.437 & -0.047 & -0.014 & -0.003 \\
\hline No child & -0.028 & 0.078 & 0.017 & 0.130 \\
\hline Hokkaido & -0.107 & -0.110 & -0.140 & -0.408 \\
\hline Tohoku & -0.040 & 0.109 & -0.145 & -0.088 \\
\hline Hokuriku-Tohsan & -0.139 & 0.043 & 0.067 & -0.031 \\
\hline Tokai & $-0.206^{* *}$ & -0.076 & -0.018 & 0.171 \\
\hline Kinki & -0.113 & 0.003 & -0.024 & -0.146 \\
\hline Chugoku-Shikoku & -0.031 & 0.032 & -0.060 & -0.177 \\
\hline Kyushu-Okinawa & -0.122 & -0.068 & 0.106 & -0.050 \\
\hline Constant & $-1.032 * * *$ & -0.228 & $-0.683 *$ & -1.014 \\
\hline Log pseudo-likelihood & -1855.4 & -2078.1 & -675.1 & -709.7 \\
\hline Sample size & 2951 & 3285 & 2951 & 3285 \\
\hline
\end{tabular}




\section{Appendix A. Questionnaire}

Actual and Ideal Happiness Questions:

1) Currently, how happy are you? Please score the degree of your happiness between 10 (very happy) and 0 (very unhappy).

2) What is your desired condition when 10 is "very happy", and 0 is "very unhappy. Please score your desired condition.

Demographic Questions:

3) Please circle your sex.

4) Please tell us your age at the time of the survey.

5) Please tell us your relationship with your family members. Do you have a partner? (regardless of legal status)

6) Please indicate your own approximate annual income (including tax).

7) What is the highest educational level that you have attained?

8) Please indicate your employment status.

9) How many children do you have? Please tell us the number of children regardless of whether or not they are dependent or independent, and living together or living separately. 


\section{Appendix B. Correlation Matrices}

\section{Correlation Matrix: Men}

\begin{tabular}{|c|c|c|c|c|c|c|c|c|c|c|c|c|c|c|}
\hline Variable & Actual happinessde & 1 happiness & Age & Married & Single & Divorced & Widowed & InIncome & high school & High school ? & -year college & Jniversity & Graduate & PermanentTemporary \\
\hline Ideal happiness & 0.47 & & & & & & & & & & & & & \\
\hline Age & 0.01 & -0.14 & & & & & & & & & & & & \\
\hline Married & 0.21 & 0.04 & 0.61 & & & & & & & & & & & \\
\hline Single & -0.17 & -0.01 & -0.67 & -0.92 & & & & & & & & & & \\
\hline Divorced & -0.09 & -0.07 & 0.00 & -0.23 & -0.09 & & & & & & & & & \\
\hline Widowed & -0.05 & -0.05 & 0.15 & -0.18 & -0.07 & -0.02 & & & & & & & & \\
\hline InIncome & 0.13 & 0.06 & 0.36 & 0.50 & -0.52 & -0.01 & -0.01 & & & & & & & \\
\hline Edu: Jr high school & -0.09 & -0.14 & 0.01 & -0.12 & 0.09 & 0.04 & 0.06 & -0.34 & & & & & & \\
\hline Edu: High school & -0.01 & -0.02 & -0.02 & -0.02 & 0.02 & 0.01 & -0.01 & -0.01 & -0.36 & & & & & \\
\hline Edu: 2-year college & 0.00 & 0.00 & -0.05 & 0.00 & 0.00 & 0.00 & -0.02 & 0.05 & -0.15 & -0.32 & & & & \\
\hline Edu: University & 0.07 & 0.11 & 0.06 & 0.10 & -0.09 & -0.03 & -0.02 & 0.22 & -0.26 & -0.54 & -0.23 & & & \\
\hline Edu: Graduate & 0.04 & 0.05 & -0.04 & 0.01 & 0.00 & -0.02 & -0.02 & 0.07 & -0.06 & -0.13 & -0.06 & -0.10 & & \\
\hline Permanent employment & 0.04 & 0.07 & -0.24 & 0.05 & -0.03 & -0.01 & -0.06 & 0.40 & -0.25 & 0.03 & 0.05 & 0.10 & 0.08 & \\
\hline Temporary employmen & -0.08 & -0.04 & -0.04 & -0.13 & 0.13 & 0.03 & 0.02 & -0.08 & 0.11 & 0.00 & -0.01 & -0.08 & -0.02 & -0.31 \\
\hline No children & -0.13 & 0.01 & -0.65 & -0.82 & 0.87 & -0.01 & -0.06 & -0.46 & 0.07 & 0.00 & 0.02 & -0.07 & 0.01 & 0.11 \\
\hline
\end{tabular}




\section{Correlation Matrix: Women}

\begin{tabular}{|c|c|c|c|c|c|c|c|c|c|c|c|c|c|c|}
\hline Variable & Actual happinessde & happiness & Age & Married & Single & Divorced & Widowed & lnIncome & Jr high school & High school? & 2-year college & University & Graduate & PermanentTemporary \\
\hline Ideal happiness & 0.48 & & & & & & & & & & & & & \\
\hline Age & -0.05 & -0.14 & & & & & & & & & & & & \\
\hline Married & 0.10 & 0.06 & 0.42 & & & & & & & & & & & \\
\hline Single & -0.05 & 0.00 & -0.65 & -0.80 & & & & & & & & & & \\
\hline Divorced & -0.08 & -0.04 & 0.03 & -0.29 & -0.11 & & & & & & & & & \\
\hline Widowed & -0.05 & -0.09 & 0.33 & -0.33 & -0.13 & -0.05 & & & & & & & & \\
\hline lnIncome & 0.00 & 0.01 & 0.12 & -0.07 & 0.00 & 0.10 & 0.06 & & & & & & & \\
\hline Edu: Jr high school & -0.07 & -0.12 & 0.06 & -0.14 & 0.07 & 0.02 & 0.14 & -0.16 & & & & & & \\
\hline Edu: High school & -0.04 & -0.05 & 0.08 & 0.04 & -0.05 & 0.02 & 0.01 & -0.01 & -0.34 & & & & & \\
\hline Edu: 2 -year college & 0.04 & 0.08 & -0.03 & 0.09 & -0.06 & -0.02 & -0.06 & 0.06 & -0.25 & -0.58 & & & & \\
\hline Edu: University & 0.08 & 0.08 & -0.11 & -0.04 & 0.08 & -0.02 & -0.06 & 0.09 & -0.14 & -0.33 & -0.25 & & & \\
\hline Edu: Graduate & -0.01 & 0.01 & -0.04 & -0.01 & 0.03 & -0.02 & -0.02 & 0.06 & -0.03 & -0.08 & -0.06 & -0.03 & & \\
\hline Permanent employment & -0.02 & 0.05 & -0.24 & -0.11 & 0.14 & 0.10 & -0.11 & 0.50 & -0.19 & 0.00 & 0.07 & 0.09 & 0.06 & \\
\hline Temporary employmen & -0.01 & -0.02 & 0.03 & 0.07 & -0.05 & -0.03 & -0.04 & 0.08 & 0.00 & 0.02 & 0.02 & -0.05 & -0.04 & -0.38 \\
\hline No children & -0.04 & 0.01 & -0.62 & -0.70 & 0.86 & -0.06 & -0.12 & 0.01 & 0.04 & -0.07 & -0.04 & 0.11 & 0.05 & $0.14-0.05$ \\
\hline
\end{tabular}




\section{References}

Abdallah, S., Thompson, S., and Marks, N. (2008). "Estimating worldwide life satisfaction”. Ecological Economics, 65, 35-47.

Albert, C., and Davia, M. A. (2005). "Education, wages and job satisfaction". Paper presented at the Epunet Conference 2005, Colchester.

Barazzetta, M. (2014). "Expectations and subjective well-being. Evidence from the BHPS". University of Nottingham, mimeo.

Becchetti, L., Castriota, S., and Londono, D. (2006). "Climate, happiness and the Kyoto protocol", CEIS Working Paper.

Binder, M., and Coad, A. (2011). "From Average Joe's happiness to Miserable Jane and Cheerful John: Using quantile regressions to analyze the full subjective well-being distribution". Journal of Economic Behavior and Organization, 79, 275-290.

Blanchflower, D.G., and Oswald, A.J. (1998). "What Makes an Entrepreneur?” Journal of Labor Economics, 16, 26-60.

Castriota, S., (2006). "Education and happiness: A further explanation to the Easterlin Paradox", mimeo.

Clark, A., (1999). "Are wages habit-forming? Evidence from micro data". Journal of Economic Behavior and Organization, 39, 179-200.

Clark, A.E. (2015). "Is Happiness the Best Measure of Well-Being?" In M. Adler and M. Fleurbaey (Eds.), Oxford Handbook of Well-Being and Public Policy. Oxford: Oxford University Press.

Clark, A.E., Frijters, P., and Shields, M. (2008). "Relative Income, Happiness and Utility: An Explanation for the Easterlin Paradox and Other Puzzles". Journal of Economic Literature, 46, 95-144.

Clark, A. E., and Oswald, A. J. (1996). "Satisfaction and Comparison Income". Journal of Public Economics, 61, 359-381.

Clark, A.E., Oswald, A.J., and Warr, P.B. (1996). "Is Job Satisfaction U-shaped in Age?" Journal of Occupational and Organizational Psychology, 69, 57-81.

Clark, A.E., Senik, C., and Yamada, K. (2013). "The Joneses in Japan: Income Comparisons and Financial Satisfaction". University of Osaka, ISER Discussion Paper No. 0866.

Cunado,J., and Gracia F. P., (2012). "Does Education Affect Happiness? Evidence for Spain”, Social Indicators Research, 108, 185-196. 
del Mar Salinas-Jiménez, M., Artés, J., and Salinas-Jiménez, J. (2013). "How Do Educational Attainment and Occupational and Wage-Earner Statuses Affect Life Satisfaction? A Gender Perspective Study". Journal of Happiness Studies, 14, 367388.

del Mar Salinas-Jiménez, M., Salinas-Jiménez, J., and Artés, J. (2014). "Education, job aspirations and subjective wellbeing: a quantile regression analysis". Universidad de Extremadura, mimeo.

Di Tella, R., MacCulloch, R. J., and Oswald, A. J. (2001). "Preferences over inflation and unemployment: Evidence from surveys of happiness". American Economic Review, 91, 335-341.

Duru-Bellat, M. (2006). L'inflation scolaire, Paris: Seuil-La République des idées.

Florida, R., Mellander, C., and Rentfow, P. J. (2013). "The happiness of cities". Regional Studies, 47, 613-627.

Ferrante, F. (2009). "Education, Aspirations and Life Satisfaction”. Kyklos, 62, 542-562.

Ferrer-i-Carbonell, A. and Frijters, P. (2004). "How important is methodology for the estimates of the determinants of happiness?", Economic Journal, 114, 641-59.

Gilboa, I., and Schmeidler, D. (2001). “A Cognitive Model of Individual Well-Being”. Social Choice and Welfare, 18, 269-288.

Hickson, H., and Dockery, A. M. (2008). "Is ignorance bliss: Exploring the links between education, expectations and happiness", 37th Australian Conference of Economists, Gold Coast.

Inglehart, R., and Klingemann, H. (2000). "Genes, culture, democracy and happiness". In E. Diener and E. Suh (Eds.), Subjective well-being across cultures. Cambridge, MA: MIT Press.

Kambayashi, R. (Ed.) (2008). Kaiko Kisei no Ho to Keizai (Law and Economics of Employment Protection). Tokyo: Nihon Hyoronsya.

Klein, S.M. and Maher, J.R. (1966). "Education Level and Satisfaction with Pay". Personnel Psychology, 19, 195-208.

Layard, R. (2005). "Happiness: Lessons From a New Science”. New York and London: Penguin.

Layard, R., Clark, A.E., and Senik, C. (2012). "The causes of happiness and misery". In J. Helliwell, R. Layard, and J. Sachs (Eds.), World Happiness Report. New York: Columbia Earth Institute.

Long, A. (2005). "Happily Ever After? A Study of Job Satisfaction in Australia”. The Economic Record, 81, 303-321. 
Mavromaras, K., Sloane, P., and Wei, Z. (2012). "The role of education pathways in the relationship between job mismatch, wages and job satisfaction: a panel estimation approach”. Education Economics, 20, 303-21.

McBride, M. (2010). "Money, Happiness and Aspirations: An Experimental Study". Journal of Economic Behavior \& Organization, 74, 262-276.

Nolen-Hoeksema, S., and Rusting, C.L. (1999). "Gender differences in well-being". In D. Kahneman, E. Diener, and N. Schwartz (Eds.), Well-being: The foundations of hedonic psychology. New York: Russell Sage Foundation.

Ohtake, F., Ohuchi, S., and Yamakawa, R. (Eds.) (2004). Kaiko Hosei Wo Kangaeru (Considering the Dismissal Regulation). Tokyo: Keiso Shobo.

Okudaira, H., Takizawa, M. and Tsuru, K. (2013). "Employment protection and productivity: evidence from firm-level panel data in Japan". Applied Economics, 45, 2091-2105.

Oreopoulos, P. (2007). "Do dropouts drop out too soon? Wealth, health and happiness from compulsory schooling”. Journal of Public Economics, 91, 2213-2229.

Oreopoulos, P., and Salvanes, K. (2011). "Priceless: the Nonpecuniary Benefits of Schooling". Journal of Economic Perspectives, 25, 159-184.

Sano, S., and Ohtake, F. (2007). Rôdô to Kôfukudo (Employment and Happiness). Nihon Rôdô Kenkyû Zasshi, 558, 4-18.

Schwandt, H. (2014). "Unmet Aspirations as an Explanation for the Age U-shape in Wellbeing". Princeton University, mimeo.

Sousa-Poza, A., and Sousa-Poza, A.A. (2000). "Well-being at work: a cross-national analysis of the levels and determinants of job satisfaction". Journal of SocioEconomics, 29, 517-538.

Stutzer, A. (2004). "The role of income aspirations in individual happiness". Journal of Economic Behavior and Organization, 54, 89-109.

van Praag, B.M. (1971). “The Welfare Function of Income in Belgium: An Empirical Investigation”. European Economic Review, 2, 337-369.

van Praag, B.M., and Kapteyn, A. (1973). "Further Evidence on the Individual Welfare Function of Income: An Empirical Investigation in the Netherlands". European Economic Review, 4, 33-62.

Veenhoven, R. (1996). "Developments in satisfaction research". Social Indicators Research, 37, 101-160.

Warr, P. (1992). “Age and Occupational Well-Being”. Psychology and Aging, 7, 37-45. 